\title{
Prevalence and predictors of colour vision defects among Egyptian university students
}

Safaa Osman, ${ }^{1}$ Shimaa Khalaf, ${ }^{1}$ Heba Mohammed, ${ }^{2}$ Dalia El-Sebaity ${ }^{3}$ and Doaa Osman ${ }^{2}$

${ }^{1}$ Department of Family and Community Health Nursing, Faculty of Nursing, Assiut University, Assiut, Egypt. ${ }^{2}$ Department of Public Health and Community Medicine, Faculty of Medicine, Assiut University, Assiut, Egypt (Correspondence to: D. Osman: doaamouhammed@aun.edu.eg). ${ }^{3}$ Department of Ophthalmology, Faculty of Medicine, Assiut University, Assiut, Egypt.

\begin{abstract}
Background: Nowadays, widespread usage of colours increases the need for accurate estimation of colour vision defects and their effect on performing daily activities and study/work tasks.

Aims: To determine the prevalence and predictors of colour vision defects among Assiut university students and to identify their relationship with self-reported visual function and perceived difficulties in performing daily activities.

Methods: A cross-sectional study was conducted among 1426 students at Assiut University, Egypt. Data were collected by self-administered questionnaire consisting of: personal characteristics, prior awareness of colour vision defects, difficulties in daily colour vision activities, and visual function. Colour vision was assessed using Ishihara's test of colour deficiency.

Results: The prevalence of colour vision defects among students was 6.9\% (red-green colour vision was $4.3 \%$ and total colour blindness was 2.6\%). Students with colour vision defects had significantly higher odds ratios for difficulties in daily activities and study/work tasks related to colour perception. Students with colour vision defects had significantly lower mean values of general health, role difficulties, and colour vision scores compared to students with normal colour insight. Male sex and family history of colour vision defects were risk factors.

Conclusions: A non-negligible percentage of Egyptian university students had colour vision defects, which had a negative impact on performing daily activities, executing study/work tasks, and choice of study/work specialties. Colour vision defects affected quality of life with regard to general health, role difficulties and colour vision. Male sex and family history of colour vision defects are nonmodifiable risk factors. This emphasizes the need for genetic counselling, especially in consanguineous marriage.

Keywords: prevalence, colour vision defects, colour blindness, visual function questionnaire, Egypt

Citation: Osman S; Khalaf S; Mohammed H; El-Sebaity D; Osman D. Prevalence and predictors of colour vision defects among Egyptian university students. East Mediterr Health J. 2021;27(4):399-406. https://doi.org/10.26719/emhj.20.128

Received: 16/01/20; accepted: 22/04/20

Copyright ( C World Health Organization (WHO) 2021. Open Access. Some rights reserved. This work is available under the CC BY-NC-SA 3.0 IGO license (https://creativecommons.org/licenses/by-nc-sa/3.o/igo)
\end{abstract}

\section{Introduction}

Colour blindness or colour vision deficiency is the inability or decreased ability to perceive colour differences under normal lighting conditions. It is one of the commonest disorders of vision and divided into congenital and acquired forms $(1,2)$. Congenital colour vision defects (CVDs) are the most common X-linked genetic disorder in humans. CVDs are more frequent in men, and the colour-deficient person can miss one or more pigments. Colour confusions are mainly between red, yellow and green hues and between blue-greens and greys. Redgreen CVD is the most common form of colour vision deficiency (3-5). Acquired CVDs reflect a problem that occurs anywhere along the visual pathway from the photoreceptors to the visual cortex (5).

Reported prevalence of CVDs varies from $1.6 \%$ to $13.99 \%$ among different countries $(6,7)$. This variation could be attributed to the precision of the conducted survey, population criteria and marriage restriction between individuals who share a common ancestor due to geographical isolation or religious belief (4).
Use of colour vision is a basic requirement in activities of daily living such as clothing, work, cooking and driving (8). CVDs can significantly negatively affect quality of life, studying and occupation, and can increase the risk of road traffic accidents (9-13). People with CVDs are at a distinct disadvantage when performing certain visual activities, and they might also be excluded from pursuing particular occupations (1).

The main risk factors for CVDs include positive family history for CVDs, male sex $(14,15)$, and consanguineous marriage (14). In Egypt, there have been few large-scale studies on prevalence rates of CVDs. A study conducted among 267 student volunteers in Menofia University Campus reported that the prevalence of red-green CVD was $8.75 \%$ (5). The present study aimed to identify the prevalence and predictors of CVDs among Assiut University students, as well as the relationship between CVDs and self-reported visual function and perceived difficulties in performing daily activities of study and work. 


\section{Methods}

\section{Study site and design}

This cross-sectional study was conducted in Assiut University, which is located in the capital city of Asyut Governorate. It is the largest university in Upper Egypt with educational capacity for nearly 70000 undergraduate students.

\section{Study population and sampling method}

The studied population was 1426 randomly selected students. The sample size was calculated using Epi-Info statistical package version 7 . The sample size was estimated for population survey with the following parameters: expected frequency $2.3 \%$ (13); an acceptable margin of error of 1.15 (16); confidence level of 95\%, and design effect 2 . The researcher used design effect 2 to increase precision of having a representative sample of the studied population. It was used to compensate for applying a multistage sampling technique instead of a simple random sample. The minimum required estimated sample size was 1304 subjects, which was raised to 1434 subjects to avoid dropout and nonrespondents. Eight subjects were excluded from the analysis due to missing data in their completed questionnaires.

Data were collected from October 2018 to March 2019. A multistage sampling technique was used for recruitment. First, a proportionate sampling technique was used to choose the faculties, including the number of students in each faculty. Six faculties were chosen: Engineering, Commerce, Law, Nursing, Dentistry and Art. Second, a simple random sampling method was used to choose the classes/sections in each faculty. From the selected classes/sections, we recruited all students who agreed to participate in the study on the survey day.

Two tools were used as follows: A self-administered questionnaire that divided into four sections 1- Personal characteristics included: age; sex; parents' consanguinity; family history of CVDs; self-reported presence of refractive error and its type; and presence of chronic disease (17). 2- Self-reported presence of CVDs includes whether the subjects thought that they had defective or normal colour vision (prior awareness of CVD). Those who were aware of their CVD were asked about the timing of their first awareness of their defect and how they recognized it (18). 3- Difficulties associated with CVDs with regard to the activities related to daily life, studying or work $(9,10,13,18)$. 4- Visual Function Questionnaire (VFQ) version 2000 was created by RAND under the sponsorship of the National American Eye Institute to measure self-reported influence of visual disability and visual symptoms on domains of general health and tasks related to daily visual functioning. It comprises 25 questions include one general health question and 11 vision-targeted constructs: global vision rating; difficulty with near vision activities; difficulty with distance vision activities; limitations in social functioning due to vision; role limitations due to vision; dependency on others due to vision; mental health symptoms due to vision; driving difficulties; limitations with peripheral vision; limitations with colour vision; and ocular pain. The researchers translated the English version into Arabic, which was revised by a linguistic consultant. Scoring, recoding and averaging of items to create subscales were conducted in accordance with the manual (19).

Assessment of colour vision: each student was assessed individually, both eyes at the same time, under good daylight using Ishihara's test of colour deficiency (24-plate edition). The plates were placed nearly $75 \mathrm{~cm}$ from the subjects and tilted so that the papers' plane was at right angles to the line of vision. The subjects were asked to read their impressions on the test plates. Differentiation of colour vision into either normal or defective (red, green or total colour blindness) was determined based on the standard guide provided with the chart.

\section{Ethical considerations}

The present study was reviewed and approved by the Nursing Ethical Review Committee of Assiut University. The ethical considerations included obtaining written informed consent, voluntary participation, and maintenance of students' privacy and confidentiality. The study was conducted in adherence with the guidelines of the Declaration of Helsinki.

\section{Statistical analysis}

Statistical analysis was done using SPSS version 16. Qualitative data are presented as frequencies and percentages while mean and standard deviation are used to express quantitative data. The reliability of VFQ was calculated and Cronbach's $\alpha$ coefficient for the scale was 0.905. After testing data normality, the Mann-Whitney test was performed to illustrate the difference between subjects with CVDs and normal visual function. Univariate logistic regression analysis was performed to identify perceived difficulties of daily activities as dependent variables (some difficulty/no difficulty) and CVD (yes/no) as an explanatory variable. Univariate and multivariable logistic regression models were applied to identify the predictors of CVDs; CVD as a dependent variable (yes/no) and the explanatory variables were sex, parents' consanguinity, presence of positive family history, self-reported presence of chronic disease, and refractive error. The significance level was considered to be $P<0.05$. Graphs were drawn using Microsoft Excel 2016.

\section{Results}

\section{Personal characteristics, correct definition of CVD, and experience with testing colour insight}

Students' age ranged from 17 to 25 years, with a mean value of 20.35 (1.5) years (Table 1). There were 840 (58.9\%) female students and parents' consanguinity was reported by $35.3 \%$ of participants. About $9 \%$ of students mentioned a positive family history of CVDs and about 
$10 \%$ had a chronic disease. About one quarter reported having refractive error and myopia was the commonest type. Only $2.7 \%$ correctly defined CVD. Twenty percent previously performed a colour blindness test and $63.6 \%$ performed it on entering university.

Table 1 Personal characteristics, correct definition of CVD, and experience with CVD testing among Assiut University students in 2018

\begin{tabular}{|c|c|c|}
\hline Variable & $\begin{array}{l}\text { Frequency } \\
(n=1426)\end{array}$ & $\begin{array}{l}\text { Percent } \\
(\%)\end{array}$ \\
\hline \multicolumn{3}{|l|}{ Age (years) } \\
\hline Mean (SD) (range) & \multicolumn{2}{|c|}{$20.35(1.5)(17-25)$ years } \\
\hline \multicolumn{3}{|l|}{ Sex } \\
\hline Male & 586 & 41.1 \\
\hline Female & 840 & 58.9 \\
\hline \multicolumn{3}{|l|}{$\begin{array}{l}\text { Consanguinity between mother and } \\
\text { father }\end{array}$} \\
\hline Yes & 503 & 35.3 \\
\hline No & 923 & 64.7 \\
\hline \multicolumn{3}{|l|}{ Family history of CVD } \\
\hline Yes & 127 & 8.9 \\
\hline No & 850 & 59.6 \\
\hline Don't know & 449 & 31.5 \\
\hline \multicolumn{3}{|l|}{ Self-reported presence of chronic disease } \\
\hline Yes & 140 & 9.8 \\
\hline No & 1286 & 90.2 \\
\hline \multicolumn{3}{|l|}{ Undergo previous eye surgery } \\
\hline Yes & 54 & 3.8 \\
\hline No & 1372 & 96.2 \\
\hline \multicolumn{3}{|l|}{ Self-reported presence of refractive error } \\
\hline Yes & 344 & 24.1 \\
\hline No & 1082 & 75.9 \\
\hline \multicolumn{3}{|l|}{ Type of refractive error $(n=344)$} \\
\hline Myopia & 259 & $75 \cdot 3$ \\
\hline Hyperopia & 47 & 13.7 \\
\hline Astigmatism & 27 & 7.8 \\
\hline Myopia and astigmatism & 11 & 3.2 \\
\hline \multicolumn{3}{|l|}{ Definition of CVD } \\
\hline Correct answer & 38 & 2.7 \\
\hline Wrong answer & 168 & 11.8 \\
\hline Don't know & 1220 & 85.5 \\
\hline \multicolumn{3}{|l|}{ Previous colour blindness test } \\
\hline Yes & 283 & 19.8 \\
\hline No & 1041 & 73.0 \\
\hline Don't know & 102 & 7.2 \\
\hline \multicolumn{3}{|l|}{ When test performed $(n=283)$} \\
\hline Entering school & 39 & 13.8 \\
\hline Entering university & 180 & 63.6 \\
\hline Military faculty examination & 56 & 19.8 \\
\hline $\begin{array}{l}\text { At entering university and military } \\
\text { faculty examination }\end{array}$ & 8 & 2.8 \\
\hline
\end{tabular}

\section{Prevalence of CVDs and prior awareness of having abnormal colour vision}

Figure 1 portrays the prevalence of CVDs among 1426 students. Combined types of CVDs were seen in 99 students (6.9\%), among whom, $4.3 \%$ had red-green colour blindness and $2.6 \%$ had total colour blindness. Higher proportions of red-green colour blindness $(7.7 \%)$ and total colour blindness $(5.5 \%)$ were detected among male than female students ( $1.9 \%$ and $0.7 \%$, respectively).

Among the 99 students with CVDs, 65 (65.7\%) were unaware of having abnormal colour vision, while 34 (34.3\%) were aware of having CVD before the survey. Prior awareness included perception of difficulties in daily activities related to colour $(n=20,58.8 \%)$, previous colour blindness test $(n=8,23.5 \%)$ and having another family member with a CVD $(n=6,17.6 \%)$. Five students $(14.7 \%)$ recognized their CVD at the primary school stage, 18 $(52.9 \%)$ at the preparatory/secondary stage and $11(32.4 \%)$ at university stage.

\section{CVDs and perceived difficulties of colour- related daily activities}

Among 99 CVD subjects, the number who perceived difficulties in daily activities based on colours was: choice of clothing colours ( $n=27,27.3 \%$ ); distinguishing the colours of tools used during hobbies and craft work $(n=18$, $18.2 \%)$; identification of flowers and plants $(n=11,11.1 \%)$; and determining the ripeness of fruit and vegetables $(n=9,9.1 \%)$ and whether meat is cooked $(n=23,23.2 \%)$. The number of CVD subjects who reported difficulties with other activities were: satisfactory adjustment of TV colour $(n=17,17.2 \%)$; recognizing skin conditions such as $\operatorname{rash}(n=20,20.2 \%)$; taking the wrong medication $(n=18$, $18.2 \%)$; and participation in or watching sports activities because of sport shirt colours $(n=15,15.2 \%)$.

For work/study tasks, the number of those who reported that CVD had a negative effect on choice of study field/work; was $15(15.2 \%)$ reported exclusion from work/study due to problems with distinguishing colours; $23(23.2 \%)$ reported having colour difficulties in their daily work/study activities; $20(20.2 \%)$ reported having colour difficulties in their previous work/study activities; and 27 (27.3\%) reported difficulties working on computers.

Table 2 shows the perceived difficulties in daily activities and work/study tasks related to colour insight. Compared to students with normal colour vision, students with CVDs had significantly higher odds ratios (ORs) for having difficulties in daily activities and work/study tasks related to colour perception. For example, choosing clothes or wall colours $(\mathrm{OR}=2.89)$, recognizing abnormal skin rash $(\mathrm{OR}=2.05)$, taking the wrong medication $(\mathrm{OR}=3.46)$, and choice of study/work field $(\mathrm{OR}=2.78)$. However, no significant differences in the perceived difficulties related to colour vision were detected between students with CVDs and normal colour vision with regard to adjustment of colours on television $(\mathrm{OR}=1.47)$ or determining ripening of fruit and vegetables $(\mathrm{OR}=0.84)$. 
Figure 1 Prevalence of colour vision defects among 1426 Assiut University students in 2018

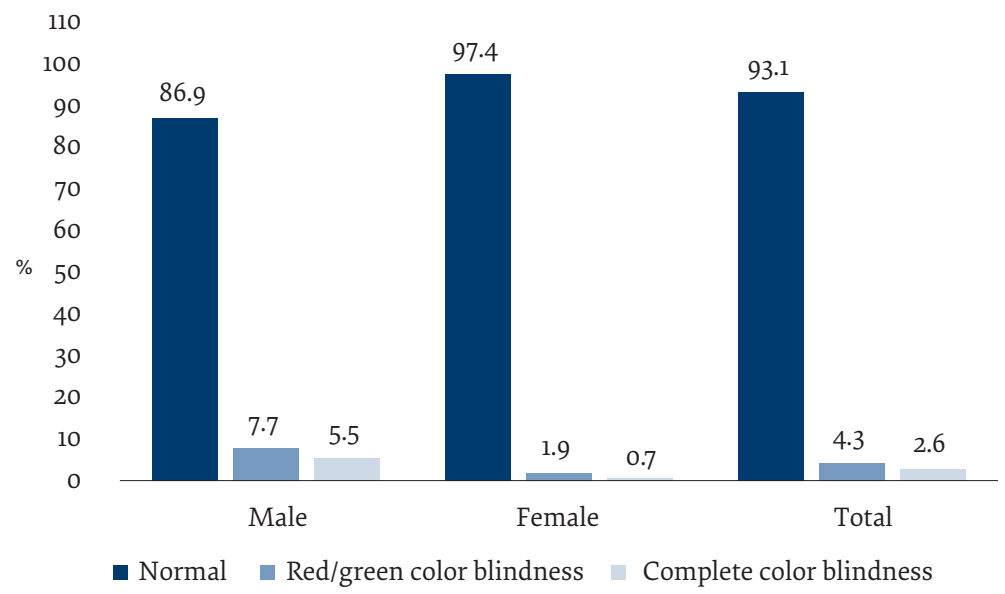

\section{CVDs in relation to self-perception of visual function}

Table 3 shows the association of CVDs with measured VFQ items. Students with CVDs had significantly lower mean values for general health, role difficulties, and colour vision scores compared to students with normal colour vision $(P<0.05)$. No significant associations were detected between CVDs and other items of visual function perception.

\section{Predictors of CVDs}

Table 4 shows that male students had significantly higher susceptibility for CVDs compared to female students $(\mathrm{OR}=6.55)$. Those with a positive family history of CVDs had significantly higher odds of having defective colour vision $(\mathrm{OR}=8.48)$. Parents' consanguinity and self-reporting presence of chronic disease or refractive error were not significant predictors of CVDs.

\section{Discussion}

There have been few studies of colour blindness in Egypt, and the present study is the first to identify the predictors of CVDs in young people in Egypt. It also explored the relationship between self-reported visual function and perceived difficulties in performing daily activities and study/work tasks among Assiut University students in Upper Egypt. The prevalence of CVDs among students was 6.9\%: red-green colour blindness was $4.3 \%$ and com-

\begin{tabular}{|c|c|c|c|}
\hline Difficulties of daily activities and study/work tasks & Odds ratio & $\begin{array}{l}95 \% \text { confidence } \\
\text { interval }\end{array}$ & $\mathbf{P}$ \\
\hline $\begin{array}{l}\text { Choosing the colours of clothes, accessories, cars, wall paint, furniture } \\
\text { and cosmetics }\end{array}$ & 2.89 & $1.81-4.65$ & $<0.001$ \\
\hline $\begin{array}{l}\text { Distinguishing the colours of wires, threads, tools, wool, paints and } \\
\text { other things during hobbies and crafts work }\end{array}$ & 2.58 & $1.49-4.47$ & 0.001 \\
\hline Identification of flowers and plants based on their colours & 2.68 & $1.36-5.29$ & 0.004 \\
\hline Determining the ripening of fruit and vegetables based on their colours & 0.84 & $0.41-1.72$ & 0.84 \\
\hline Determining if meat is cooked based on its colour & 1.86 & $1.14-3.05$ & 0.013 \\
\hline Satisfactory adjustment of TV colour balance & 1.47 & $0.85-2.54$ & 0.168 \\
\hline Recognizing skin conditions such as rash and sunburn & 2.05 & $1.21-3.44$ & 0.007 \\
\hline Taking the wrong medication because of difficulties with their colours & 3.46 & $1.98-6.055$ & $<0.001$ \\
\hline $\begin{array}{l}\text { Participation in or watching of sports activities because of sport shirt } \\
\text { colours }\end{array}$ & 3.21 & $1.76-5.84$ & $<0.001$ \\
\hline Choosing of study field/work affected by colour vision & 2.78 & $1.53-5.04$ & 0.001 \\
\hline $\begin{array}{l}\text { Exclusion from work/study due to problems with distinguishing } \\
\text { colours }\end{array}$ & 4.88 & $2.71-8.80$ & $<0.001$ \\
\hline Having colour difficulties in daily work/study activities? & 4.84 & $2.88-8.14$ & $<0.001$ \\
\hline Having colour difficulties in previous work/study activities? & 4.16 & $2.42-7.16$ & $<0.001$ \\
\hline Work on computer & 2.60 & $1.62-4.17$ & $<0.001$ \\
\hline
\end{tabular}

Univariate regression analysis; difficulties in daily activities and study/work tasks (dependent variable), CVD (explanatory variable).

$\mathrm{CVD}=$ colour vision defect. 


\begin{tabular}{|c|c|c|c|}
\hline Variables & $\begin{array}{c}\text { CVD } \\
(n=99) \text { mean (SD) }\end{array}$ & $\begin{array}{l}\text { Normal colour perception } \\
(n=1327) \text { mean (SD) }\end{array}$ & $\mathbf{P}^{*}$ \\
\hline General health & $57.82(29.59)$ & $65.32(26.81)$ & 0.015 \\
\hline General vision & $80.60(17.25)$ & $78.70(23.61)$ & 0.91 \\
\hline Ocular pain & 78.28 (21.93) & $82.23(20.96)$ & 0.05 \\
\hline Near activities & 88.67 (15.14) & 89.86 (15.29) & 0.40 \\
\hline Distant activities & $88.72(14.54)$ & $89.05(15.88)$ & 0.49 \\
\hline \multicolumn{4}{|l|}{ Vision specific } \\
\hline Social functioning & 89.52 (16.43) & $91.21(16.48)$ & 0.13 \\
\hline Mental health & $82.32(19.23)$ & $85.34(17.61)$ & 0.169 \\
\hline Role difficulties & $78.40(26.11)$ & $83.24(25.51)$ & 0.039 \\
\hline Dependency & 89.98 (19.12) & $92.89(17.08)$ & 0.205 \\
\hline Driving & $82.73(20.52)$ & $85.91(18.87)$ & 0.249 \\
\hline Color vision & $86.22(21.57)$ & $91.34(18.64)$ & 0.003 \\
\hline Peripheral vision & $90.15(17.06)$ & $90.20(18.96)$ & 0.64 \\
\hline
\end{tabular}

${ }^{*}$ Mann-Whitney U test. CVD = colour vision defect.

plete color blindness was $2.6 \%$. A higher prevalence of CVDs was found among male students (red-green colour blindness was $7.7 \%$ and total colour blindness was $5.5 \%)$ compared to female students $(1.9 \%$ red-green colour blindness and $0.7 \%$ total colour blindness). The higher prevalence observed among male students was mainly due to the X-linked recessive inheritance of CVDs (1).

Similar prevalence rates of CVDs (8.75\%) were reported by an Egyptian study conducted in Menofia University Campus (5) and in a Turkish survey (7.33\%) on 941 young healthy men (20). An Iraqi study in Erbil City, Kurdistan Region, among 1856 preliminary, secondary and college students found a prevalence of red-green colour blindness of $6.25 \%$ (8.47\% among male and $1.37 \%$ among female students) (21). A study in Northern India among 1028 children found that the prevalence of CVDs ranged from $5.26 \%$ to $11.36 \%$ among boys and $0-3.03 \%$ among girls (2). Another Indian cross-sectional study among Muslims in Manipur found that the prevalence of red-green colour blindness was $5.28 \%(8.73 \%$ in male and $1.69 \%$ in female participants) (17).

However, different results were observed in some other studies. A higher prevalence of CVDs was reported in an Iranian population-based study conducted among
3132 participants in Mashhad $13.93 \%$ in the total study population; $15.85 \%$ in male and $12.96 \%$ in female participants) (7). The prevalence of CVDs among male secondary school students in Jizan City, Saudi Arabia was $21.3 \%$ (14). The difference might be explained by the inclusion of a wider age range, racial differences or higher rate of parents' consanguinity. Other studies have reported lower prevalence rates. A study conducted among 1305 public school children in Durban, South Africa, found a prevalence of CVDs of $2.2 \%$ (4.2\% in boys and $0.6 \%$ in girls) (22). A study conducted among 1635 Nigerian students from public secondary school found that the prevalence of CVDs was $2.3 \%$ (3.8\% among boys and $0.9 \%$ among girls) (13). A Jordanian study conducted among 1418 university students from Zarka Private University and the Hashemite University reported a prevalence of red-green colour blindness of $1.6 \%$ (8.72\% among men and $0.33 \%$ among women) (6).

A lower prevalence of CVDs was observed among students who enrolled in practical faculties, especially medical education. For example, among medical students in Nepal, prevalence of CVDs was 5.6\% (23). Prevalence of CVD was $1.6 \%$ among 303 first-cycle students of the Faculty of Medicine and Biomedical Sciences of the

\begin{tabular}{|c|c|c|c|c|c|c|}
\hline \multirow[t]{2}{*}{ Risk factors } & \multicolumn{3}{|c|}{ Unadjusted } & \multicolumn{3}{|c|}{ Adjusted } \\
\hline & OR & $95 \%$ CI & $\mathbf{P}$ & OR & $95 \% \mathrm{CI}$ & $\mathbf{P}$ \\
\hline Male sex & 5.63 & $3.46-9.15$ & $<0.001$ & 6.55 & $3.92-10.94$ & $<0.001$ \\
\hline Family history of CVD (Yes) & 7.34 & $4.62-11.67$ & $<0.001$ & 8.48 & $4.98-14.45$ & $<0.001$ \\
\hline Parent consanguinity (Yes) & 1.51 & $1.0-2.29$ & 0.049 & 0.91 & $0.57-1.46$ & 0.706 \\
\hline Presence of chronic disease (Yes) & 2.03 & $1.17-3.53$ & 0.012 & 1.44 & $0.75^{-2.76}$ & 0.275 \\
\hline Refractive error (Yes) & 1.33 & $0.85-2.09$ & 0.214 & 1.33 & $0.80-2.23$ & 0.274 \\
\hline
\end{tabular}

Unadjusted and adjusted regression models of CVD: dependent variable was CVD, reference categories for explanatory variables were; female sex, family history (no), parents' consanguinity (no), presence of chronic disease (no), and presence of refractive error (no).

$\mathrm{CI}=$ confidence interval; $\mathrm{CVD}=$ colour vision defect; $\mathrm{OR}=$ odds ratio. 
University of Yaoundé, Cameroon (24). CVD prevalence was $1.77 \%$ among 1126 preparatory students (3.5\% among men and $0.5 \%$ among women) who subsequently join Saudi colleges of medicine, dentistry, applied medical sciences, nursing, and clinical pharmacy (15). This might be explained by the presence of strict health prerequisites for practical faculties and students' awareness of their CVDs that limited their opportunity or willingness to join medical, paramedical and nursing faculties.

Difficulties have been reported among people with CVDs in performing everyday tasks such as hobbies, plant/flower identification, ripeness of fruits and vegetables, and taking the wrong medication $(9,13,18,22)$. Moreover, they reported that it could affect their choice of and exclusion from certain occupations or study fields. Similarly, in the present study, students with CVDs had significantly higher odds of having difficulties related to colour perception in daily activities and work/study tasks compared to students with normal colour vision.

No previous studies have explored the relationship of CVDs with the VFQ. In the current study, CVDs had a limited effect on quality of life with regard to vision. Students with CVDs had a significantly worse perception of general health, role difficulties, and colour vision compared to students with normal colour vision. In contrast, no significant differences were detected in other domains of the VFQ, such as difficulty with near/ distance vision activities, social functioning limitations, dependency on others, mental health symptoms, driving difficulties, limitations with peripheral vision, and ocular pain. These domains were reported to be affected by disorders related to visual acuity, cataract, nuclear opacity and optic neuritis (25-27).

In the current study, male students and students with a positive family history of CVDs had significantly higher susceptibility for CVDs. Consistent with these results, a study done in Jizan City, Saudi Arabia revealed that CVDs were significantly associated with positive family history (14). Another Saudi study, in Makkah, found that male sex and positive family history of CVDs were significant predictors for CVDs (15). Positive family history seems closely associated with high consanguinity in populations carrying the genes responsible for the CVDs in the family. Adjusted regression in the current study showed that parents' consanguinity was not a risk factor for CVDs. Variations in the association of CVDs with parents' consanguinity were reported in the Saudi studies $(14,15)$.

Self-reporting the presence of refractive error was not a risk factor for CVDs in the present study. These results were consistent with a study conducted among preparatory Saudi university students at Makkah, where CVDs were not significantly associated with other visual defects (15).

\section{Conclusions and recommendations}

We found that a non-negligible percentage of Egyptian university students had CVDs, especially among male students, and a large proportion were unaware of their CVD. The study provides a snapshot of CVDs among Egyptian students. However, it is of limited value as it reflects the size of the problem only among university students. A large, representative study of young people (both students and non-students) in different Egyptian regions is recommended to determine the prevalence of CVDs throughout Egypt. In this study, CVD had a negative impact on performing daily activities, executing study/work tasks, and choice of study/work specialties. Moreover, it affected the quality of life with regard to general health, role difficulties and colour vision. Male sex and having a positive CVD family history increased the risk of CVDs. Unfortunately, sex and positive family history are nonmodifiable risk factors for CVDs. It is recommended that those who have a positive family history of CVDs ask for genetic counselling, especially in consanguineous marriage. Moreover, studies should be performed to mitigate the difficulties perceived by people with CVD subjects in colour-vision activities.

Funding: None.

Competing interests: None declared.

\section{Prévalence et facteurs prédictifs des anomalies de la vision des couleurs chez les étudiants égyptiens \\ Résumé}

Contexte: Actuellement, l'utilisation généralisée des couleurs augmente la nécessité d'une estimation précise des anomalies de la vision des couleurs et de leurs effets sur l'exécution des activités quotidiennes ainsi que sur les tâches d'étude/de travail.

Objectifs: Déterminer la prévalence et les facteurs prédictifs des anomalies de la vision des couleurs chez les étudiants de l'Université d'Assiout et identifier leur relation avec la fonction visuelle autodéclarée et les difficultés perçues dans l'exécution des activités quotidiennes.

Méthodes: Une étude transversale a été menée auprès de 1426 étudiants de l'Université d'Assiout (Égypte). Les données ont été recueillies au moyen d'un questionnaire auto-administré portant sur les caractéristiques personnelles, la connaissance préalable des anomalies de la vision des couleurs, les difficultés au niveau des activités quotidiennes liées à la vision des couleurs et la fonction visuelle. La vision des couleurs a été évaluée à l'aide du test d'Ishihara sur la déficience dans la perception des couleurs. 
Résultats : La prévalence des anomalies de la vision des couleurs chez les étudiants était de 6,9\% (anomalies de la vision des couleurs de type rouge-vert 4,3\% et daltonisme total 2,6\%). Les étudiants ayant des anomalies de la vision des couleurs avaient des odds ratios significativement plus élevés pour les difficultés liées à l'exécution des activités quotidiennes et des tâches d'étude/de travail liées à la perception des couleurs. Ceux qui avaient des anomalies de la vision des couleurs présentaient des valeurs moyennes significativement plus faibles pour la santé générale, les difficultés liées au rôle et les scores de vision des couleurs par rapport aux étudiants ayant une perception normale des couleurs. Le sexe masculin et les antécédents familiaux d'anomalies de la vision des couleurs constituaient des facteurs de risque de ces dernières.

Conclusions: Un pourcentage non négligeable d'étudiants universitaires égyptiens présentaient des anomalies de la vision des couleurs. Ces anomalies avaient un impact négatif sur l'exécution des activités quotidiennes, des tâches d'étude/de travail ainsi que sur le choix des spécialités. Elles affectent la qualité de vie pour ce qui concerne la santé générale, les difficultés liées au rôle et la perception de la vision. Le sexe masculin et les antécédents familiaux des anomalies de la vision des couleurs sont des facteurs de risque non modifiables de ces dernières. Cela souligne la nécessité du conseil génétique, en particulier dans le cas des mariages consanguins.

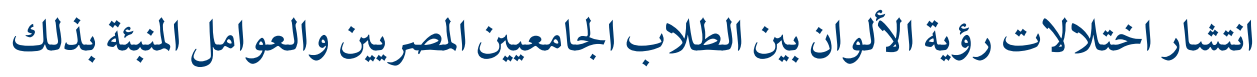

$$
\begin{aligned}
& \text { صفاء عثمان، شيماء خلف، هبة محمد، داليا السبتي، دعاء عثمان }
\end{aligned}
$$

الخلفية: في الوقت الحاضر، زاد انتشار استخدام الألوان على نطاق واسع من الحاجة إلى تقدير دقيق لاختلالات رؤية الألوان وتأثيرها على أداء

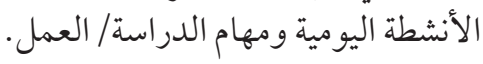

الأهداف: هدفت هذه الدراسة إلى: تحديد مدى انتشار اختلالات رؤية الألو ان والعو امل المنبئة بذلك بين طلاب جامعة أسيوط وطئ وتحديد علاقتها

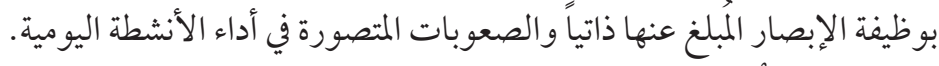

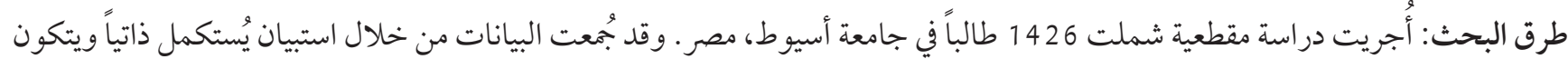

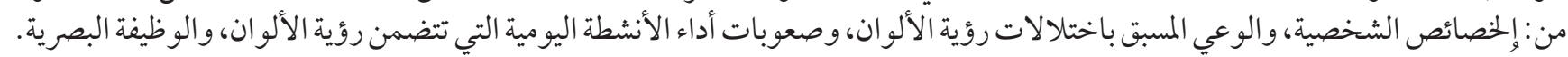

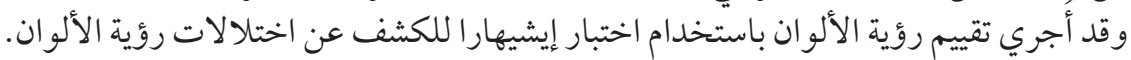

النتائج: بلغت نسبة انتشار اختلالات رؤية الألوان بين الطلاب 9.6 \%٪ (بلغت نسبة اختلال رؤية اللونين الأحمر والأخضر 3. 4.

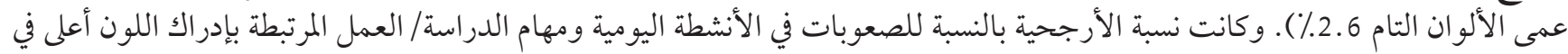

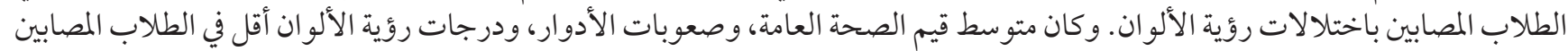

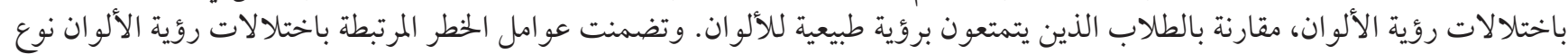

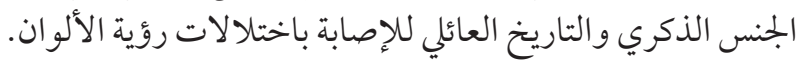

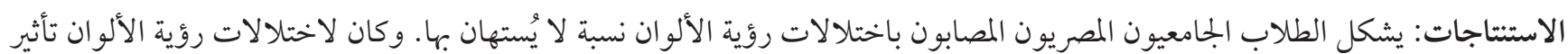

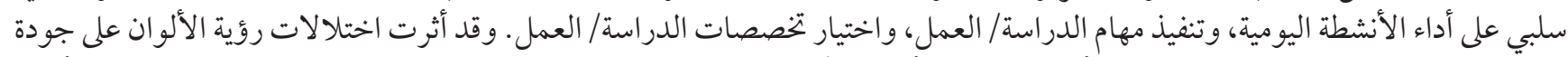

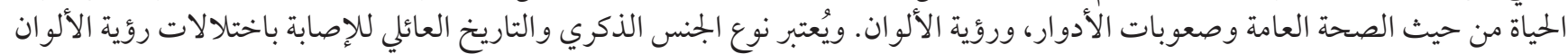

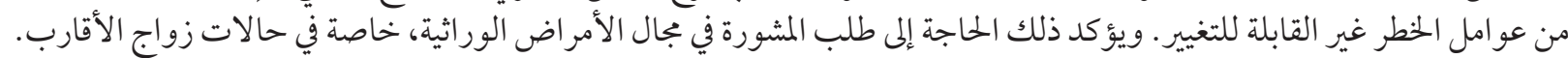

\section{References}

1. Simunovic MP. Colour vision deficiency. Eye, 2010 May;24(5):747-55 http://dx.doi.org/10.1038/eye.2009.251 PMID:19927164

2. Fareed M, Anwar MA, Afzal M. Prevalence and gene frequency of color vision impairments among children of six populations from North Indian region. Genes Dis. 2015 Jun;2(2):211-8. https://doi.org/10.1016/j.gendis.2015.02.006.

3. Deeb SS. Molecular genetics of color-vision deficiencies. Vis Neurosci. 2004 May-Jun;21(3):191-6 http://dx.doi.org/10.1017/ S0952523804213244 PMID: 1551818

4. Birch J. Worldwide prevalence of red-green color deficiency. J Opt Soc Am A Opt Image Sci Vis. 2012 Mar 1;29(3):313-20 http:// dx.doi.org/10.1364/JOSAA.29.000313 PMID: 2247276

5. Marey HM, Semary NA, Mandour SS. Ishihara electronic color blindness test: An evaluation study. Ophthalmol Res Int J. 2015 Dec 16;3(3):67-75. https://doi.org/10.9734/OR/2015/13618

6. Al-Aqtum MT, Al-Qawasmeh MH. Prevalence of colour blindness in young Jordanians. Ophthalmologica. 2001 Jan-Feb;215(1):3942 http://dx.doi.org/10.1159/000050824 PMID: 1112526 
7. Hashemi H, Khabazkhoob M, Pakzad R, Yekta A, Heravian J, Nabovati P, et al. The prevalence of color vision deficiency in the northeast of Iran. J Curr Ophthalmol. 2019 Mar;31(1):80-5 http://dx.doi.org/10.1016/j.joco.2017.05.005

8. Barry JA, Mollan S, Burdon MA, Jenkins M, Denniston AK. Development and validation of a questionnaire assessing the quality of life impact of Colour Blindness (CBQoL). BMC Ophthalmol. 2017 Oct 2;17(1):179. http://dx.doi.org/10.1186/s12886-017-0579-z PMID:28969674

9. Tagarelli A, Piro A, Tagarelli G, Lantieri PB, Risso D, Olivieri RL. Colour blindness in everyday life and car driving. Acta Ophthalmol Scand, 2004 Aug;82(4):436-42. http://dx.doi.org/10.1111/j.1395-3907.2004.00283.x PMID:15291938

10. Cole BL. The handicap of abnormal colour vision. Clin Exp Optom. 2004 Jul;87(4-5):258-75. http://dx.doi. org/10.1111/j.1444-0938.2004.tb05056.x PMID:15312030

11. Ramaswamy S, Hovis JK. Do color-deficient observers take longer to complete a color-related task? Optom Vis Sci. 2009 Aug;86(8):964-70. http://dx.doi.org/10.1097/OPX.obo13e3181b2f7c1 PMID:19609227

12. Owsley C, McGwin Jr G. Vision and driving. Vision Res. 2010 Nov;50(23):2348-61. http://dx.doi.org/10.1016/j.visres.2010.05.021.

13. Ugalahi M, Fasina O, Ogun O. Impact of congenital color vision defect on color-related tasks among secondary school students in Ibadan, Southwest Nigeria. Niger J Ophthalmol. 2016;24(1):20-4. http://dx.doi.org/10.4103/0189-9171.179914

14. Dahlan HM, Mostafa OA. Screening for Color Vision Defects among Male Saudi Secondary School Children in Jizan City, Kingdom of Saudi Arabia. Med J Cairo Univ. 2013 Jun;81(2):513-7.

15. Khairoalsindi OA, Almasoudi BM, Bamahfouz AY, Alghamdi AA, Siddiqui MI. Prevalence and determinants of color vision defects among preparatory university students at Makkah, Saudi Arabia. Middle East Afr J Ophthalmol. 2019 Sep 30;26(3):133-7. http://dx.doi.org/10.4103/meajo.MEAJO_29_19 PMID:31619899

16. Naing L, Winn T, Rusli B. Practical issues in calculating the sample size for prevalence studies. Arch Orofacial Scie. 2006;1:9-14.

17. Shah A, Hussain R, Fareed M, Afzal M. Prevalence of Red-green color vision defects among muslim males and females of Manipur, India. Iran J Public Health. 2013;42(1):16-24. PMID:23515069

18. Steward JM, Cole BL. What do color vision defectives say about everyday tasks? Optom Vis Sci. 1989 May;66(5):288-95. http:// dx.doi.org/10.1097/00006324-198905000-00006 PMID:2787492

19. Mangione CM, Lee PP. Gutierrez PR, Spritzer K, Berry S, Hays RD. Development of the 25-item National Eye Institute Visual Function Questionnaire. Arch Ophthalmol. 2001 Jul;119(7):1050-8. http://dx.doi.org/10.1001/archopht.119.7.1050 PMID:11448327

20. Citirik M, Acaroglu G, Batman C, Zilelioglu O. Congenital color blindness in young Turkish men. Ophthalmic Epidemiol, 2005 Apr;12(2):133-7. http://dx.doi.org/10.1080/09286580590932743 PMID:16019694

21. Karim KJ, Saleem MA. Prevalence of congenital red-green color vision defects among various ethnic groups of students in Erbil City. Jordan J Biol Sci. 2013;147(898):1-4. http://dx.doi.org/10.12816/0001540

22. Mashige KP. Impact of congenital color vision defect on color-related tasks among schoolchildren in Durban, South Africa. Clin Optom. 2019;11:97-102. http://dx.doi.org/10.2147/OPTO.S204332 PMID:31496857

23. Pramanik T, Khatiwada B, Pandit R. Color vision deficiency among a group of students of health sciences. Nepal Med Coll J. 2012 Dec 1;14(4):334-6.

24. Dohvoma VA, Ebana Mvogo SR, Kagmeni G, Emini NR, Epee E, Mvogo CE. Color vision deficiency among biomedical students: a cross-sectional study. Clin Ophthalmol. 2018 Jun 19;12:1121-4. Httop://dx.doi.org/10.2147/OPTH.S160110 PMID:29950807

25. Cole SR, Beck RW, Moke PS, Gal RL, Long DT. The National Eye Institute Visual Function Questionnaire: experience of the ONTT. Optic Neuritis Treatment Trial. Invest Ophthalmol Vis Sci. 2000 Apr;41(5):1017-21. PMID:10752936

26. Clemons TE, Chew EY, Bressler SB, McBee W. National Eye Institute Visual Function Questionnaire in the Age-Related Eye Disease Study (AREDS): AREDS Report No. 10. Arch Ophthalmol. 2003 Feb;121(2):211-7. http://dx.doi.org/10.1001/archopht.121.2.211. PMID:12583787

27. Gyawali R, Paudel N, Adhikari P. Quality of life in Nepalese patients with low vision and the impact of low vision services. J Optom. 2012 Oct;5(4):188-95. http://dx.doi.org/10.1016/j.optom.2012.05.002. 